\title{
On Integration of Teaching Plan of Electronic Information Major Based on Work Process Orientation
}

\author{
Zhen $\mathrm{Yu}^{1}$, Li Xilin ${ }^{2}$ \\ ${ }^{1}$ Chengdu University of Technology, Chengdu, 610059, China
}

Keywords: Work process. Orientation. Electronic information major. Teaching. Plan. Integration

\begin{abstract}
In teaching electronic information major, the teaching plan based on work process orientation can be implemented to expand teaching dept hand breadth. Since the previous teaching mode cannot adapt teaching demand, improvement is required. In the implementation process, it is required to analyze teaching effects. The author discusses integration of teaching plan of electronic information major based on work process orientation according to practical conditions and hopes to provide some reference data for related workers.
\end{abstract}

\section{Introduction}

Electronic information is a very abstract science with strong profession. Many colleges in China set up this subject, but the teaching is dominated by stating factuality and argumentation. Thus, students' knowledge structure cannot meet enterprise needs. So, it is required to adopt work-oriented teaching mode in order to improve students' practical ability and make them adapt future work.

\section{Shortcomings of traditional teaching methods in electronic information major}

\section{Teaching ideas and concepts fall behind; teachers think little of practice and pay attention to theories \\ In electronic information major, practice is an essential link and can greatly help cultivate students' ability. But, many colleges fail to set up enough practice courses and cannot satisfy teaching demands. The ideology of many teachers falls behind. They think little of practice and pay attention to theories. They overemphasize the guiding effect of theories on practice. Thus, students lack innovation awareness and cannot ponder over and solve problems. Meanwhile, they cannot flexibly apply the knowledge they learn.}

Practical teaching contents are old-fashioned and cannot have the due effects

Practical teaching contents will impose certain influences on the quality of practical teaching. Currently, teaching materials used by many colleges were prepared many years ago. There is no teaching program for practice. So, such phenomena as old-fashioned teaching contents and few practice items exist. Nowadays, electronic information industry develops very rapidly. Thus, electronic information major must continuously expand the teaching contents, or else teaching will become old-fashioned. However, many colleges fail to value this point and cross multiple subjects in practical teaching. Practice courses even become auxiliary course of theoretical teaching. Besides, in practical teaching, there are too many demonstration and verification projects and few comprehensiveness and design projects.

Teaching devices and equipment fall behind

As electronic information develops rapidly, electronic instruments and products upgrade very rapidly, too. Due to the shortage of funds, many colleges cannot timely replace teaching instruments and equipment. The replacement rate cannot keep up with the development of electronic information industry. When students practice and operate, the instruments and equipment used are not just laggard. Besides, the property is also poor. The component model is very old-fashioned, greatly different from the equipment currently used in the society. The students cultivated with such devices and equipment will be disconnected with practical environment of electronic information industry. Meanwhile, it is hard for the, to adapt post requirements. 


\section{Teaching environment is unreasonable}

Teaching environment is the required condition and place for teaching activities and has very great influences on overall teaching effects. In practical teaching, many colleges adopt the mode of large class. The number of students in a classroom can even reach 100. Facing so many students, teachers cannot interact with students in limited space and time. It is also difficult for teachers to find problems. In the link of experimental course, since experimental course is different from theoretical course, the duration of asking and answering questions between students and teachers in equipment use process will be more than that of theoretical course. Thus, in the large-class experimental course, it is almost impossible to interact and exchange between teachers and students. In addition, larger class scale means the knowledge students can receive is less.

\section{Teachers' ability and quality are insufficient}

In some vocational colleges, since colleges lack professional electronic information teachers, external recruitment mode is adopted. The teachers recruited externally are short of ability ad quality. Meanwhile, this makes electronic information course system chaotic. Besides, electronic information major has features of complexity and systematicness. If teachers' professional ability is insufficient or do not know clearly teaching objectives and emphases, they cannot well guide students. Colleges fail to adopt related measures to train teachers. Moreover, this major also requires teachers owning rich operation experience and excellent practical ability which many teachers lack.

\section{Integration of teaching plan of electronic information major based on work process orientation}

The course system based on work orientation introduces the whole work process into teaching and combines post needs to impart knowledge to students. Meanwhile, the course system based on work orientation pays special attention to cultivation of students' professional ability. It presents real work tasks and social products to students so as to make teaching more visual, operable and practical. Through the application and exploration in recent years, this method has been widely applied in many colleges. This paper analyzes application ad integration of this method.

\section{Deep survey of posts related to electronic information major}

Colleges need to investigate and survey related enterprises and know enterprises' post duties and related vocational certificates so as to provide basis and lay a foundation for formulating next course. Meanwhile, it is required to conduct in-depth analysis according to work tasks of enterprises, confirm the cultivation objectives of electronic information major and describe work tasks, including task equipment, tool, object of work and labor organization etc. After the survey, it is required to make the experiment in the core course and then implement the course.

\section{Design of learning field, learning situation and course}

It is required to design courses according to work-oriented basic theory. In-depth analysis of enterprise posts has been done above. It is necessary to associate the post duties and tasks to gradually form learning field of this major. For example, since enterprises badly need analog electronic technology, oscillating circuit and power circuit should serve as the key points. It is also required to actively expand the learning field.

Learning situation is the materialization of learning field. During the design, it is required to specify professional cultivation objective of every situation, select rational teaching methods and provide necessary environment for situation implementation. Moreover, course standards should be perfected. Course standards refer to course title, class quantity, class content and class evaluation. Only when course standards are perfected can good guiding effects be realized for the whole class.

\section{Rational implementation of course system}

It is required to flexibly arrange teaching, adjust according to practice time and campus training so as to take full advantage of teaching resources and realize close cooperation between colleges and enterprises. For instance, the output of an enterprise is large in July-August and the enterprise is badly in need of personnel. The college can organize students to practice in the enterprise so as to improve their practical ability. 
Furthermore, colleges can adopt the "workshop-type" teaching mode as to form integration of "teaching, learning and practice", move the classroom to the workshop and combine theoretical knowledge and practical knowledge. But, colleges must increase investment and introduce the equipment and hardware for workshop training for the sake of students' future development.

\section{Integration of teaching plan}

Finally, it is required to integrate teaching plan and propose higher requirements for students' ability structure. Professional ability structure includes many aspects, such as occupational basic ability, core occupational competence and occupational expansion ability. Occupational basic ability requires students owning good professional ethics and correctly cognizing work except the fundamental operation skills. Occupational expansion ability requires students owning certain organizing ability, management ability, adaptive capacity and feeling capacity for aesthetics and colors. To cultivate students' expansion ability, Computer Art, Photography, Management \& Negotiation and other courses can be set up.

Core occupational competence has many requirements. Firstly, students are required to grasp simulation software Multisim and map-making software Protel. This can be realized through setting up computer-assisted course. Students also must be able to proficiently operate Photoshop software. Secondly, students are required to install, debug and use computer network, normally calculate, analyze and design digital electronic circuit. In addition, color TV maintenance technology and operation specification for electricians are also important parts students should master. Finally, students should have the ability to apply singlechip to develop automatic control system. So, colleges need to set up computer aided design course, graph and image processing course, circuit analysis course, color TV maintenance course and application of singlechip technology etc.

\section{Enhancement of hardware facility construction of colleges}

To achieve teaching objectives and boost students' practical ability, hardware facility construction of colleges must be enhanced. Colleges should set up electronic laboratory, electrician laboratory, singlechip experience base, PLC laboratory, maintenance laboratory for household appliances and simulation laboratory etc. according to features of hardware facility construction of colleges major. The colleges with good economic conditions can also establish complex laboratory for electronic information major so that students can carry out analog simulation experiments for digital electronics, high-frequency electron beam and automatic control. The construction of hardware facilities can help students master the principles and design modes of electronic system and build a bridge between theoretical teaching and practice.

\section{Analysis and evaluation of course effects}

\section{Mastery degree of basic theoretical knowledge}

Electronic information major involves a large quantity of professional theoretical knowledge. If students cannot master theoretical knowledge, they cannot operate well. So, it is required to evaluate students' mastery degree for basic theoretical knowledge. Examination paper mode can be adopted. Test questions must be reliable and professional. Besides, the difficulty degree and distinction degree must be appropriate in order to well evaluate students' mastery degree for theoretical knowledge. The students of 3 grades in electronic information major were selected randomly for examination. They were required to answer the choice question, gap filling questions and picture drawing questions. The results show the pass rate and average score of junior students are lower than those of sophomores and freshmen. Sophomores and freshmen experiencing course system reform based on work process orientation are superior to junior students in mastery of theoretical knowledge.

\section{Operational capacity}

Only when students own operational capacity can they quickly adapt the work. To cultivate students' operational capacity is also an important objective of colleges. For the students majoring in electronic information, they must learn to identify and measure various electron components and master methods of application of various electronic instruments. Finally, they should be able to proficiently weld, assemble and maintain all kinds of electronic products. To evaluate students' 
operational ability, 66 students in Grade 2010 were selected to participate in examination of intermediate certificate for household appliance maintenance. There are many examination contents of intermediate certificate for household appliance maintenance, including trouble removal, circuit diagram surveying and mapping, instrument application and measurement etc. These can well test students' operational ability. Among the 66 students predicating in the examination, 59 students passed trouble removal; 52 students passed instrument application and measurement; 54 students passed circuit diagram surveying and mapping. The students passing the three items can gain the certificate. Among the 66 students, certificate acquisition rate reaches 82.8\%. Thus, the teaching method based on work process orientation can to some extent improve students' operational ability.

\section{Innovation ability and development ability}

Innovation refers to recreation of existing technological achievements. Contemporary college students must own innovation ability and development ability for the sake of future development. Through evaluation of innovation ability and development ability, teaching quality and effect can be known. Currently, most colleges only pay attention to theory and neglects practice. Thus, students' creative ability and development ability cannot improve. For this, colleges can reform educational pattern and guide students to take part in extracurricular activities. After the work-oriented teaching plan is implemented, students' innovation ability and development improve to some extent. Colleges will hold electronic design competitions annually. Students will exhibit their design works. Some students even participate in provincial and national related competitions. In Grade 2010, 23 students participated in electronic design competition for nationwide college students. One won the first place; 3 gained the second place; one won the third place. Meanwhile, this also reflects the advantages and effects of work-oriented teaching method.

\section{Summary and experience}

After work-oriented teaching method is adopted, electronic information major improves a lot. Moreover, students' practical ability and comprehensive quality also improve. Course reform needs long-term practice and exploration. The teaching objectives can really be achieved and professional personnel can be cultivated for the society only through reform and innovation.

\section{References}

[1] Zhu jiejing, On practical teaching reform of electronic information major in vocational colleges [J]. Education Exploration, 2013(9): 42-43

[2] Yuan Kaihong, Liu Hongbing, Application of multiple intelligence in integrated teaching of electronic information technology major in vocational colleges [J]. E-world, 2013(17): 168-168,F0003

[3] Chen Chunming, Exploration of electronic information course teaching reform in automation major - analysis of Huizhou Zhongkai Technician Training School [J]. China Science and Technology Review, 2013(29): 6-6

[4] Zhu Yan, Cultivation of applied talents with online education platform - taking electronic information major in Grade 2010 of Ankang University for example [J]. Henan Science \& Technology: first, 2013(10): 282-282

[5] You Wenjian, Research on integration of teaching plan of electronic information major based on work process orientation [J]. Management \& Technology of SME, 2011(27): 216-217 